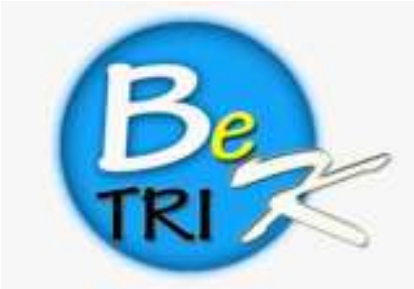

ISSN : $2339-1871$

\title{
DIAGNOSA PENYAKIT MANUSIA MENGGUNAKAN MODEL SISTEM PAKAR
}

\author{
Ahmat Josi ${ }^{1}$ \\ Dosen STMIK PRABUMULIH ${ }^{1}$ \\ Jln. Patra No 50 Kelurahan Sukaraja Kecamatan Prabumulih Selatan, Sumatera Selatan, Indonesia \\ Sur-el : Ahmat_Josi@yahoo.com ${ }^{1}$
}

\begin{abstract}
Disease is a cause of disturbance in living things, disorders caused by bacteria, viruses or abnormalities of the physiological system or tissues in organs. Many ways can be done to find out the problems associated with the disease one of them by consulting to doctors, clinics and even hospitals, but the way costs are high enough, so sometimes made people suffering from disease. Many choose to keep silent while doing recovery traditional. The development of information technology is currently very supportive of provide solutions to the problem such as the development of expert system applications that can help diagnose disease and provide solutions for free.
\end{abstract}

Keywords: Disease, Expert System, information technology

\begin{abstract}
Abstrak: Penyakit adalah suatu yang menyebabkan gangguan pada mahluk hidup, gangguan disebabkan oleh bakteri, virus atau kelainan sistem faal atau jaringan pada organ tubuh. Banyak cara yang bisa dilakukan untuk mengetahui permasalahan yang berhubungan dengan penyakit salah satunya dengan konsultasi ke dokter, klinik bahkan rumah sakit, namun cara tersebut membutuhkan biaya yang cukup tinggi, sehingga terkadang membuat orang yang menderita penyakit, banyak memilih untuk berdiam diri sembari melakukan pemulihan secara tradisional. Perkembangan teknologi informasi saat ini sangat mendukung untuk memberikan solusi terhadap masalah tersebut misalnya pembangunan aplikasi sistem pakar yang bisa membantu mendiagnosa penyakit dan memberikan solusi secara gratis.
\end{abstract}

Kata kunci: Penyakit, Sistem Pakar, teknologi informasi

\section{PENDAHULUAN}

Perkembangan teknologi informasi saat ini berkembang pesat, ini terbukti dengan banyaknya pengembang-pengembang aplikasi yang membangun aplikasi dengan tujuan untuk mempermudah user atau pengguna menyelesaikan permasalahannya. Salah satu aplikasi yang bisa dimanfaatkan adalah aplikasi yang menerapkan model sistem pakar.

Sistem pakar (expert system) secara umum adalah sistem yang berusahamengadopsi pengetahuan manusia ke komputer, agar komputer dapatmenyelesaikan masalah seperti yang biasa dilakukan oleh para ahli (Rohman\&Amin, 2008), selain itu sistem 
pakar juga dapat diartikan sebagai suatu sistem yang yang dirancang untuk mengetahui bidang tertentu yang sudah di program oleh seorang programer. Sistem pakar biasanya dibuat untuk mendiagnosa atau melakukan identifikasi awal dari suatu permasalahan seperti mendiagnosa virus komputer, mediagnosa buta warna, penyakit pada tumbuhan bahkan penyakit pada manusia.

$$
\text { Penyakit adalah suatu yang }
$$
menyebabkan gangguan pada mahluk hidup, gangguan disebabkan oleh bakteri, virus atau kelainan sistem faal atau jaringan pada organ tubuh. (KBBI). Banyak cara yang bisa dilakukan untuk mengetahui permasalahan yang berhubungan dengan penyakit salah satunya dengan konsultasi ke dokter, klinik bahkan rumah sakit, namun cara tersebut membutuhkan biaya yang cukup tinggi, sehingga terkadang membuat orang yang menderita penyakit, banyak memilih untuk berdiam diri sembari melakukan pemulihan secara tradisional.

Dari latar berlakang diatas maka penulis tertarik untuk mengangkat topik atau judul yaitu "Diagnosa Penyakit Manusia Menggunakan Model Sistem Pakar" dengan tujuan mempermudah user atau pengguna aplikasi untuk mengetahui gejala awal dari penyakit yang dideritanya.

\section{METODOLOGI}

Metode penelitian Adalah suatu penyelidikan yang sistematis untuk meningkatkan sejumlah pengetahuan, juga merupakan suatu usaha yang sistematis dan terorganisasi untuk menyelidiki masalah tertentu yang memerlukan jawaban ( A Josi, 2017). Sedangkan menurut sugiyono (2013:2) metode penlitian adalah Metode penelitian pada dasarnya merupakan cara ilmiah untuk mendapatkan data dengan tujuan dan kegunaan tertentu. Adapun metodologi penelitian yang digunakan dalam penelitian ini adalah metode deskriptif kualitatif, deskriptif kualitatif adalah data informasi yang berbentuk kalimat verbal bukan berupa simbol angka atau bilangan.

\subsection{Metode Pengembangan Sistem}

Metode pengembangan sistem yang digunakan ialah model Rapid Application Development (RAD) . RAD merupakan model proses perangkat lunak yang menekankan pada daur pengembangan hidup yang singkat (Pressman, 2010). Adapun tahapan-tahapan dari metode RAD adalah

1. Bussines Modeling

2. Data Modelling

3.Process Modelling

\section{Application Generation}

5.Testing and turnover. Gamabar RAD dapat dilihat pada gambar berikut

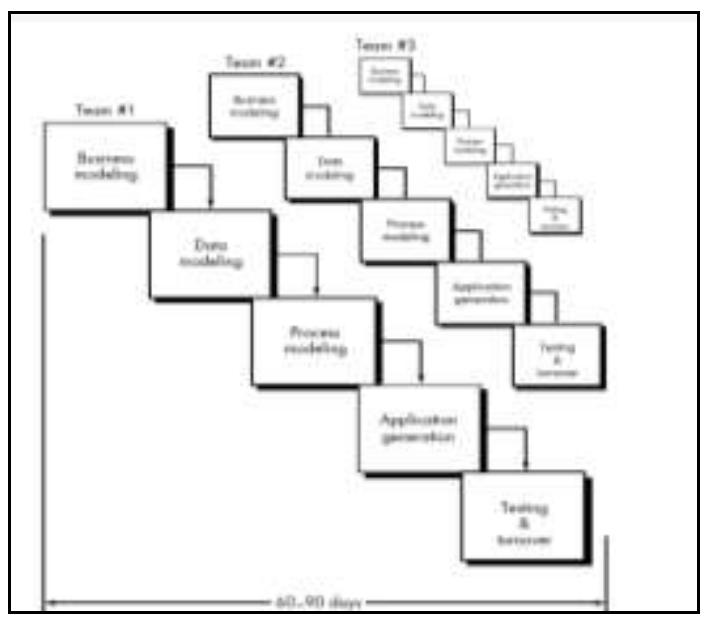

Gambar 1. RAD 
Beberapa keuntungan dalam menggunakan metode RAD adalah sebagai berikut:

1. Membeli sistem yang baru memungkinkan untuk lebih menghemat biaya ketimbang mengembangkan sendiri.

2. Proses pengiriman menjadi lebih mudah, hal ini dikarenakan proses pembuatan lebih banyak menggunakan potonganpotongan script.

3. Mudah untuk diamati karena menggunakan model prototype, sehingga user lebih mengerti akan sistem yang dikembangkan.

4. Lebih fleksibel karena pengembang dapat melakukan proses desain ulang pada saat yang bersamaan.

5. Bisa mengurangi penulisan kode yang kompleks karena menggunakan wizard.

6. Keterlibatan user semakin meningkat karena merupakan bagian dari tim secara keseluruhan.

7. Mampu meminimalkan kesalahankesalahan dengan menggunakan alat-alat bantuan (CASE tools)

Adapun kekurangan dari Metode RAD adalah sebagai berikut :

1) Dengan melakukan pembelian belum tentu bisa menghemat biaya dibandingkan dengan mengembangkan sendiri.

2) Membutuhkan biaya tersendiri untuk membeli peralatan-peralatan penunjang seperti misalnya software dan hardware.

3) Kesulitan melakukan pengukuran mengenai kemajuan proses.
4) Kurang efisien karena apabila melakukan pengkodean dengan menggunakan tangan bisa lebih efisien.

5) Ketelitian menjadi berkurang karena tidak menggunakan metode yang formal dalam melakukan pengkodean.

6) Lebih banyak terjadi kesalahan apabila hanya mengutamakan kecepatan dibandingkan dengan biaya dan kualitas.

7) Fasilitas-fasilitas banyak yang dikurangi karena terbatasnya waktu yang tersedia.

8) Sistem sulit diaplikasikan di tempat yang lain.

9) Fasilitas yang tidak perlu terkadang harus disertakan, karena menggunakan komponen yang sudah jadi, sehingga hal ini membuat biaya semakin meningkat karena harga komponen yang lebih lengkap semakin mahal.

\subsection{Analisis dan Perancangan}

\subsubsection{Analisis}

Analisis adalah penguraian pokok persoalan atas bagian-bagian, penelaahan bagian-bagian tersebut dan hubungan antar bagian untuk mendapatkan pengertian yang tepat dengan pemahaman secara keseluruhan, dalam hal ini penulis melakukan analisa terhadap kebutuhan sistem yang akan digunakan. (A Josi, 2016) analisis dapat juga diartikan adalah sekumpulan aktivitas dan proses. Salah satu bentuk analisis adalah merangkum sejumlah besar data yang masih mentah menjadi informasi yang dapat diinterpretasikan. Semua bentuk analisis berusaha menggambarkan pola-pola secara konsisten dalam data sehingga hasilnya dapat 
dipelajari dan diterjemahkan dengan cara yang singkat dan penuh arti.

\subsubsection{Perancangan Sistem}

A. Rancangan halaman utama

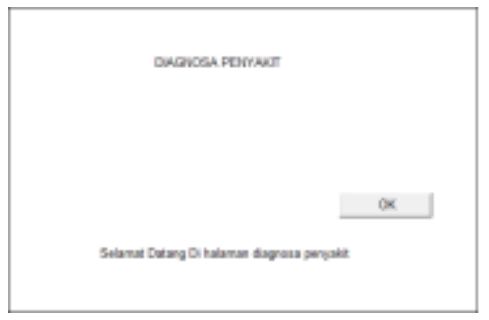

Gambar 2. Rancangan Halaman Utama

B. Rancangan halaman Pertanyaan

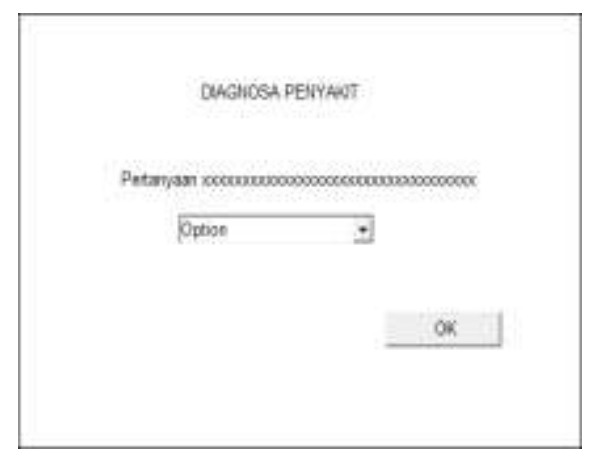

Gambar 3. Rancangan HalamanPertanyaan

B. Rancangan halaman Hasil

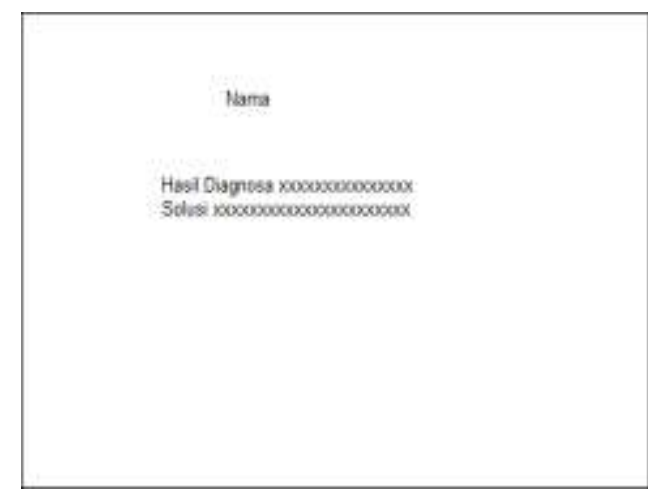

Gambar 4. Rancangan Halaman Hasil

\section{HASIL}

\subsection{Penerapan Metode RAD}

\subsubsection{Bussines Modeling}

Pada tahapan business process adalah analisis proses bisnis terhadap sistem yang akan dibangun. Analisis ini membuat identifikasi awal dari perencanaan sistem

\subsubsection{Data modeling}

Pada tahapan ini pekerjaan yang dilakukan adalah mendefinisikan dari fase business modeling disaring ke dalam serangkaian objek data yang dibutuhkan untuk menopang bisnis tersebut.Pemodelan data yang dibuat adalah berdasarkan kebutuhan sistem yang akan dibangun. Dalam fase ini juga pengembang merancang skema database yang digunakan yang dibentuk dalam table table berikut ini

Table 1. table admin

\begin{tabular}{lll}
\hline Name & Tipe Data & Value \\
\hline Username & Varchar & 20 \\
\hline Pasword & Varchar & 20 \\
\hline
\end{tabular}

Table admin berfungsi untuk menampung data admi, admin berfungsi untuk menginput data pertanyaan dan jawaban dari sumber-sumber yang legal.

Table 2. Pertanyaan

\begin{tabular}{lll}
\hline Name & Tipe Data & Value \\
\hline No & Int & 10 \\
\hline Pertanyaan & Text & 200 \\
\hline Jawaban & Varchar & 200 \\
\hline
\end{tabular}

Table pertanyaan berfungsi untuk menampung seluruh pertanyaan yang diinput oleh admin, pertanyaan tersebut merupakan pertanyaan yang dimanfaatkan untuk 
melakukan identifikasi awal dari suatu penyakit pada manusia. Table ini nantinya akan di kombinasikan dengan coding sehingga prosedurnya dapat berjalan sesuai dengan harapan dari pengembang.

\subsubsection{Process modeling}

Pada tahapan process modeling pekerjaan yang dilakukan adalah membuat alur proses dari sistem atau aplikasi yang akan dibangun. Alur proses yang dibuat tersebut mencakup input data, proses pertanyaan dan lainnya.berikut adalah alur proses dari sistem yang digambarkan dalam bentuk flowchart

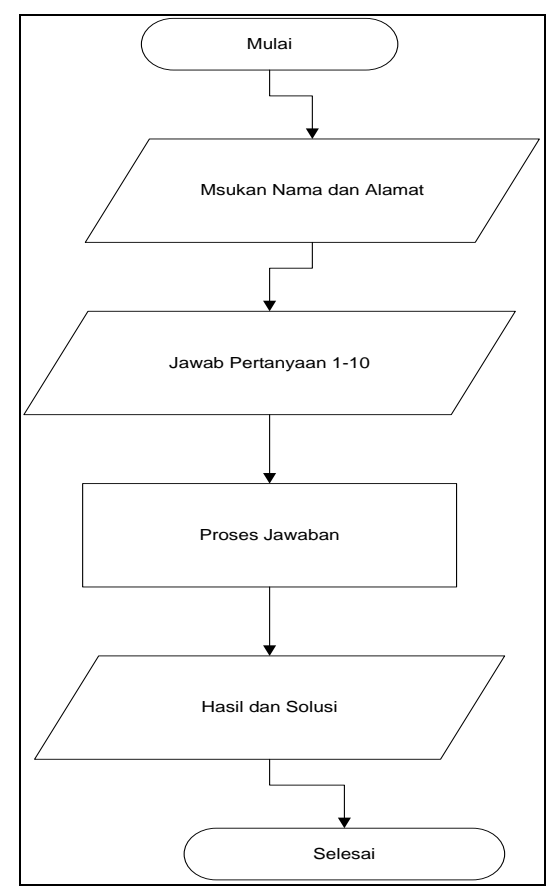

Gambar 5. Flowchart alur proses

\subsubsection{Application generation}

Tahapan application generation pekerjaan yang dilakukan adalah melakukan penkodean atau implementasi dari process modeling dan data modeling. Berikut adalah contoh pengkodean dalam aplikasi sistem pakar.

$<$ ?php

require "connection.php";

\$first $=$ \$_POST['first_select'];

\$second $=$ \$_POST['second_select'];

\$third $=$ \$_POST['third_select' $]$;

\$fourth $=$ \$_POST['fourth_select'];

\$fifth $=$ \$_POST['fifth_select'];

\$sixth $=$ \$_POST['sixth_select'];

\$seventh $=$ \$_POST['seventh_select'];

\$eight $=$ \$_POST['eight_select'];

\$nineth $=$ \$_POST['nineth_select'];

\$tenth $=\$$ _POST['tenth_select'];

\$nama $=$ \$_POST['nama'];

\$lokasi $=$ \$_POST['lokasi'];

$\$$ satu $=\$$ first $*-0.25$

$\$$ dua $=\$$ second $* 0.5$;

$\$$ tiga $=\$$ third $*-0.5 ;$

\$empat $=$ \$fourth $*-0.714$;

$\$$ lima $=\$$ fifth $* 1$;

\$enam $=\$$ sixth $* 0.167$

$\$$ tujuh $=\$$ seventh $* 0.583 ;$

\$delapan $=$ \$eight $* 0.43$;

\$sembilan $=$ \$nineth $* 0.77$;

$\$$ sepuluh $=\$$ tenth $* 0.22 ;$

\$hasil $=\max (\$$ satu, $\$$ dua, \$tiga, \$empat, \$lima, \$enam, \$tujuh, \$delapan, \$sembilan, \$sepuluh);

if $($ hasil $==\$$ satu $)\{$

\$hasil1 = "Rematik"; 


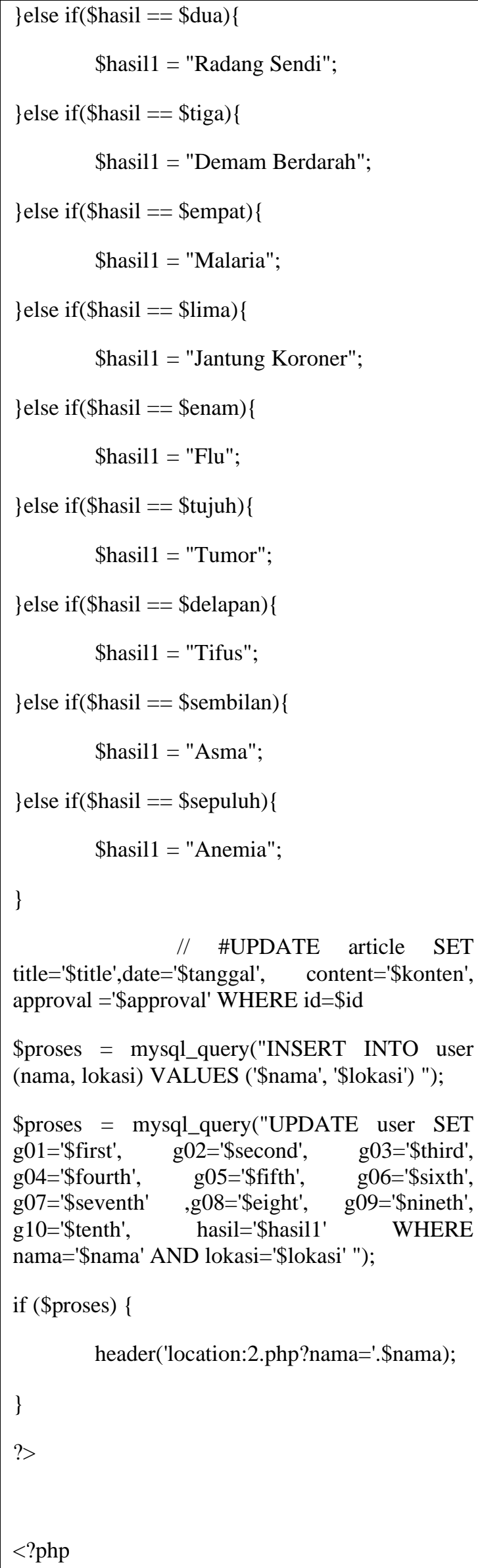

require "connection.php";

\$nama $=$ \$_POST['nama'];

\$lokasi = \$_POST['lokasi'];

\$proses = mysql_query("INSERT INTO user (nama, lokasi) VALUES ('\$nama', '\$lokasi') ");

\section{if (\$proses)}

header("location:1.php?name=" \$nama);

\}else\{

echo "damn you!";

\}

?>

$<$ ?php

require "connection.php";

$\$$ data $=\operatorname{array}() ;$

\$query = mysql_query("SELECT DISTINCT gejala FROM gejala");

$\$$ idx $=0$;

\$jmlh = mysql_num_rows $($ \$query $)$;

while(\$row

mysql_fetch_array(\$query)) \{

\$idx++); for $(\$ i d x ; \quad \$ i d x<\$ j m l h ;$

\$row['gejala']); array_push $(\$$ data,

\}

/*

for $(\$ i d x=0 ;$ idx $<$ jimlh; $\$$ idx ++$)\{$

echo \$data[\$idx];

echo "<br>";

\}$* /$ 


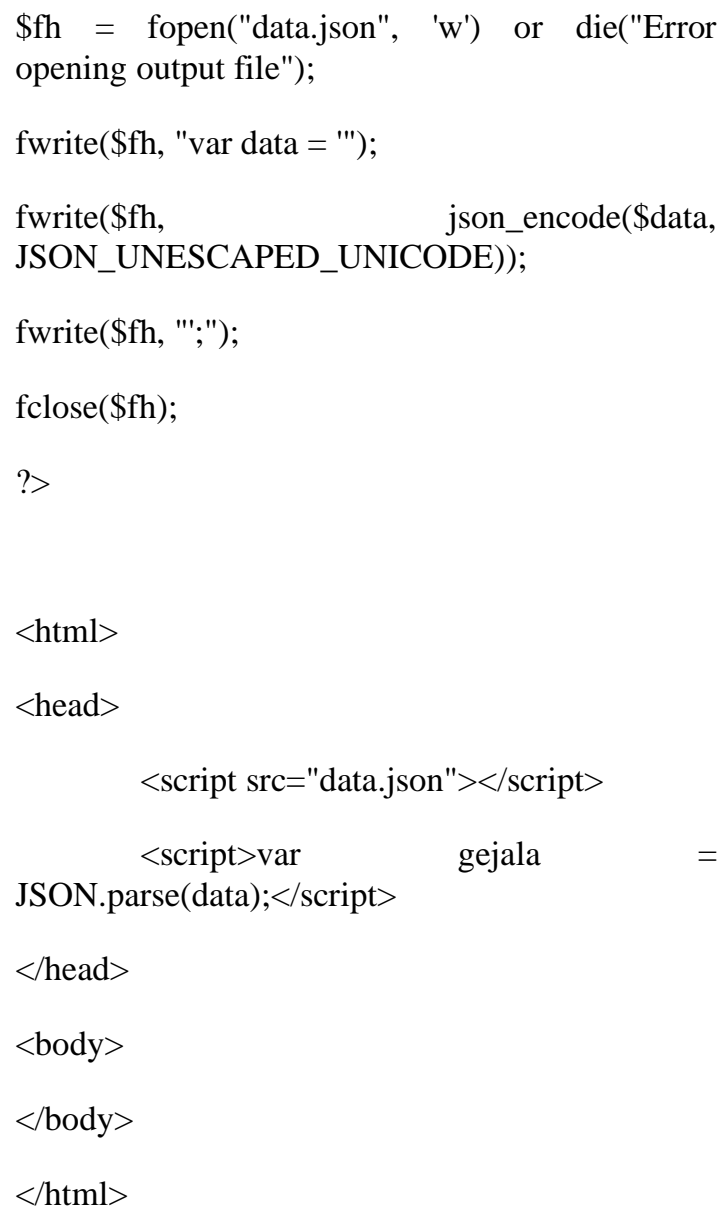

\subsubsection{Testing and turnover}

Pada tahapan testing, pekerjaan yang dilakukan adalah melakukan pengujian sistem pakar yang telah dibuat. Pengujian tersebut menggunakan pengujian balck-box, pengujian top down (A Josi, dkk, 2014) dan white-box (Mujilahwati, 2014). Berikut adalah tampilan hasil pengujian menggunakan balck-box testing

Table 3. Pengujian Black-Box

\begin{tabular}{llll}
\hline No & $\begin{array}{l}\text { Scenario } \\
\text { pengujian }\end{array}$ & Tes Case & Kesimpulan \\
& Masuk ke & $\begin{array}{l}\text { Masuk } \\
\text { halaman }\end{array}$ & Valid \\
& halaman & utama & \\
& utama & & \\
\hline
\end{tabular}

\begin{tabular}{llll}
\hline 2 & Masuk ke & Masuk & Valid \\
& Halaman & $\begin{array}{l}\text { Halaman } \\
\text { Pertanyaan }\end{array}$ & \\
& Pertanyaan & & \\
\hline 3 & Masuk ke & Masuk & Valid \\
& halaman Hasil & halaman & \\
& Diagnosa & Hasil & \\
& & Diagnosa & \\
& & \\
\hline
\end{tabular}

Pengujian yang kedua yaitu pengujian topdown. Berikut adalah hasil pengujian top-down

Table 4 Pengujian Top Down

\begin{tabular}{l|l|l|l}
\hline \multicolumn{4}{c}{ Halaman Utama } \\
\hline P & I & G & L \\
\hline P1 & I1 & G1 & L1 \\
\hline
\end{tabular}

Sedangkan proses pengujian dengan menggunakan white box terbagi menjadi tiga, yang bisa dilihat dari flowchart berikut.

Flowchart alur sistem

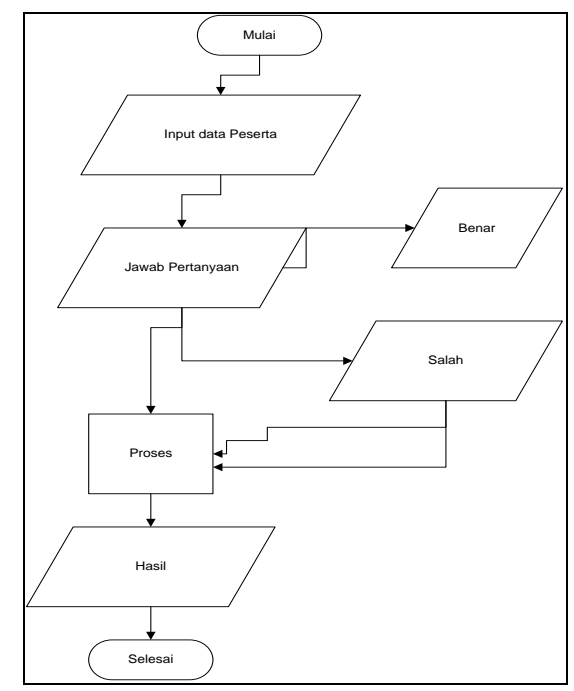

Gambar 6. Flowchart White-Box

Berikut alur proses admin sistem. 


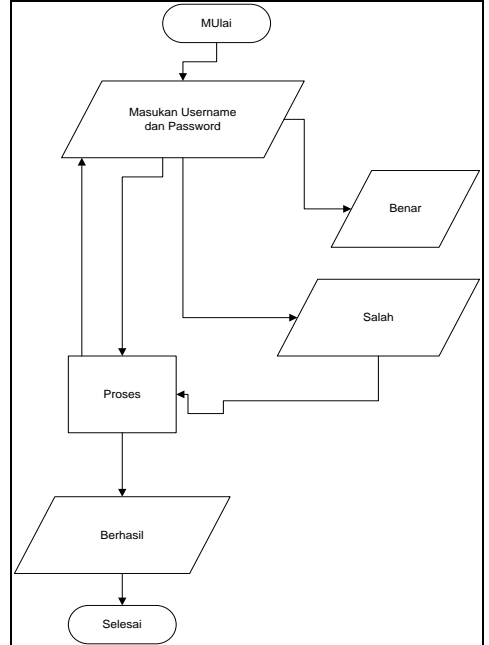

Gambar 7. Flowchart Alur Admin

Berdasarkan pengujian yang telah dilakukan dapat disimpulkan bahwa siste pakar dapat berjalan dengan baik,dan sesuai dengan perancangan sistem.

\subsubsection{Tampilan Interface}

\section{A. Halaman Utama}

halaman utama ialah halaman yang pertama kali tampil ketika aplikasi di akses, halaman ini menunjukan awal untuk mengakses ke halaman berikutnya.

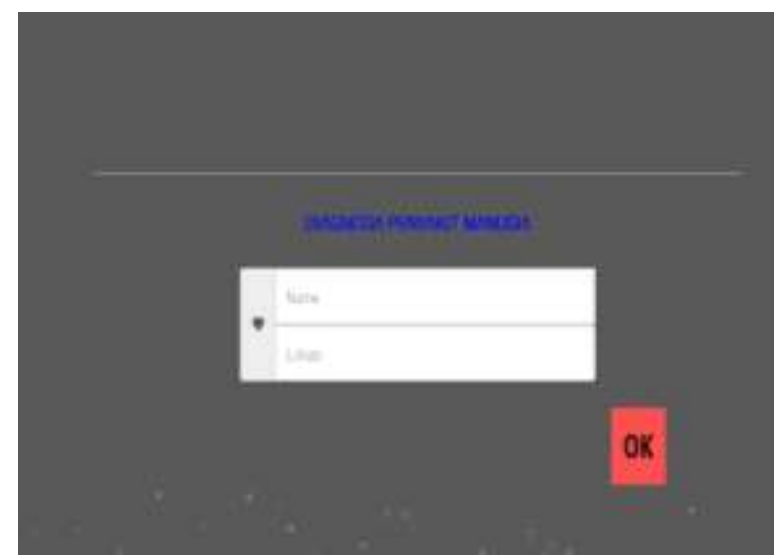

Gambar 8. Rancangan Halaman Utama

B. Tampilan Halaman Isi Identitas
Halaman ini berisi pendataan identitas, calon pengguna aplikasi, dalam halaman ini user diharuskan untuk mengisi nama dan lokasi tempat tinggal misalnya seperti pada gambar ini, nama diisi dengan nama iman dan lokasi atau alamat di isi prabumulih, setelah selesai maka user bisa melanjutkan dengan menekan tombol ok, dan aplikasi akan masuk ke halaman selanjutnya, yaitu halaman pertanyaan yang berisi pertanyaan diagnosa penyakit.

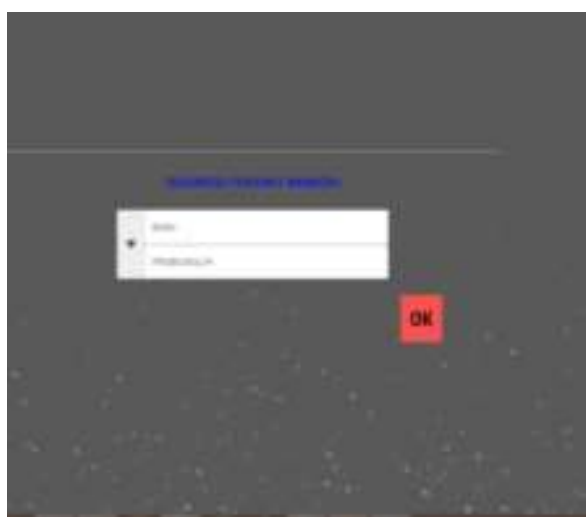

Gambar 9. Rancangan Halaman Utama

C. Tampilan Halaman Pertanyaan

Halaman ini berisi pertanyaan yang telah ditentukan oleh sistem dan di input oleh admin, yang pertanyaan diambil dari sumber, buku-buku kesehatan dan refrensi kesehatan, pertanyaan ini terdiri dari sepuluh pertanyaan dengan tujuh opsi atau pilihan

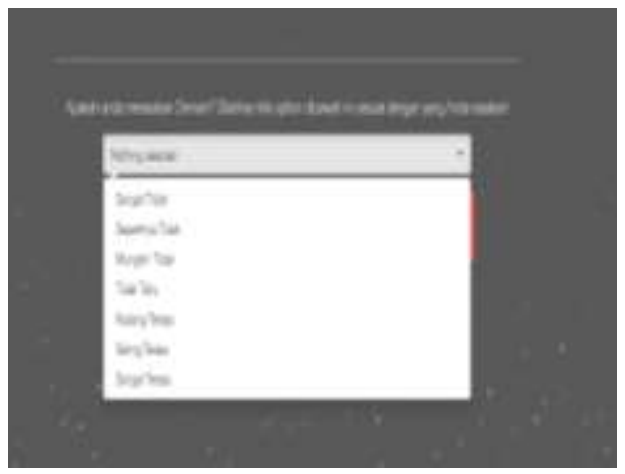

Gambar 10. Rancangan Halaman Utama 
D. Tampilan Pertanyaan Berikutnya

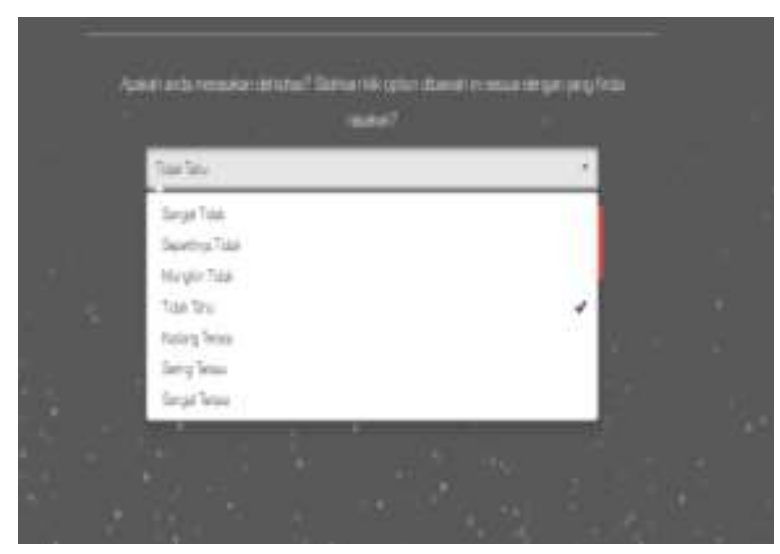

Gambar 11. Rancangan Halaman Utama

\section{E. Tampilan Hasil Diagnosa}

Halaman ini merupakan halaman hasil dari diagnosa yang telah dilakukan aplikasi, diagnosa diambil dari jawaban atas pertanyaan-pertanyaan yang telah di input oleh admin. Hasil dari diagnosa merupakan identifikasi awal terhadap gejala penyakit pada manusia, dan diberikan alternatif solusi yang harus dilakukan untuk menangani penyakit tersebut .

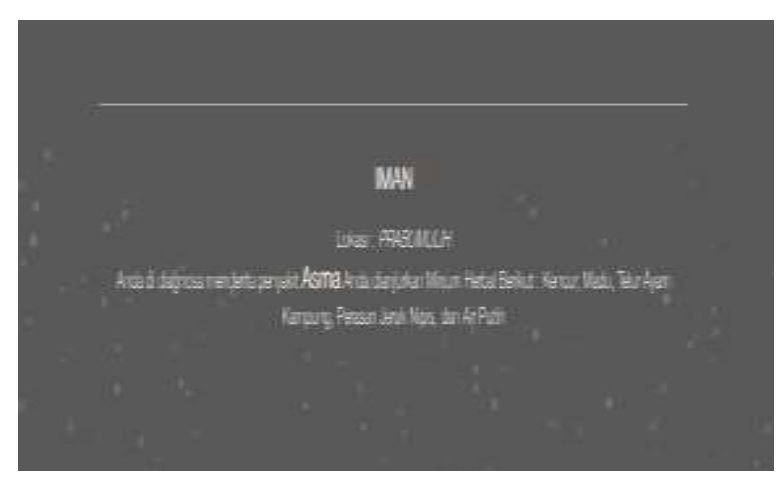

Gambar 12. Halaman hasil diagnosa

\section{SIMPULAN}

Berdasarkan penelitian tersebut dapat disimpulkan beberapa hal yaitu sebagai berikut

1. Sistem dapat berjalan dengan baik

2. Sistem dapat mendiagnosa awal penyakit manusia

3. Sistem ini berbasis web sehingga jika sewaktu-waktu ingin di hosting, akan lebih mudah dan dapat digunakan oleh masyarakat luas.

4. Sistem ini dibangun dengan model Rapid Application Development (RAD)

5. Saat ini hanya ada beberapa penyakit saja yang di inputkan oleh admin

\section{DAFTAR RUJUKAN}

Rohman And Ami, 2008. Rancang Bangun Aplikasi Sistem Pakar Untuk Menentukan Jenis Gangguan Perkembangan Pada Anak. Media Informatika, Vol. 6, No. 1, Juni 2008, 123 ISSN: 0854-4743

A Josi, 2017. Perancangan Dan Implementasi E-Jurnal Pada Unit Penelitian Dan Pengabdian Masyarakat (UP2M) Stmik Prabumulih. JIPN (Journal of Informatics Pelita Nusantara). Volume 1 No 2 Maret 2017, ISSN 2541-3724 